DOI 10.31558/2519-2949.2021.2.12

УДК 323.2.48(477.83/.86)(091)

ORCID ID: https://orcid.org/0000-0001-5502-8367

Павлюх М. В., Національний університет «Львівська політехніка», Украӥна

\title{
ЧАСОПИС СОЮЗУ УКРАЇНОК «ГРОМАДЯНКА» ЯК ПОЛІТИЧНИЙ ОРГАН ДРУЖИНИ КНЯГИНІ ОЛЬГИ
}

Проаналізовано головну тематику, жанри, статті часопису Союзу українок «Громадянка». Досліджено матеріали, в яких жінки пропагували начіональну ідею, формували начіональну свідомість. Виокремлено головний тематичний контент патріотичного видання «Громадянка». Вивчено організацію роботи редакиії: рубрики та відділи. Подано головні публікації, в яких автори статей проводили політичну пропаганду проти польської окупачійної влади. 3'ясовано, щэо видання Союзу Українок «Громадянка» формувало на своӥх шпальтах жіночий патріотизм, будило політичну свідомість. Вказано головні напрями діяльності жіночої патріотичної організаџї Дружсина княгині Ольги, яка діяла у Галичині першої половини ХХ століття.

Украӥнська начіональна ідея стала наскрізною ідеєю часопису. Орган патріотичної української жіночої організації Дружсина княгині Ольги відіграв важливу роль у політичному житті Галичини першої половини ХХ століття, оскільки об'єднав патріотичних жінок у боротьбі за політичні свободи. Активність жінки-матері, жінки-берегині сімейного вогнища, жінки-патріотки підтримувалася виданням як головна ідейна компонента багатьох статей. Політична пропаганда на шпальтах видання «Громадянка» формувала громадську думку, насамперед, сільського жіночтва, яке не завжди мало змогу читати та навчатися.

У статті проаналізовані кілька важливих публікачій, які демонструють головні тематичні напрями. Видання «Громадянка» пропагувало здоровий спосіб життя серед сільського жіноцтва, а також формувало начіональні иінності серед населення: любов до рідної мови, традииій, звичаїв, культури, батьківщини. Діяльність Дружини княгині Ольга та ї̈ друкованого і політичного органу - видання «Громадянка» набули широкого розмаху у галицькому краї, тому польський окупачійний режим неодноразово конфісковував чергові числа та номери. Вагомість, вплив та роль видання «Громадянка» серед галищького населення значні, оскільки політична пропаганда проти ворожої влади та украӥнська національна ідея сприяли визвольній боротьбі українського народу у першій половині ХХ століття.

Ключові слова: жіноча преса, "Дружина княгині Ольги", украӥнська начіональна ідея, начіональна свідомість, політична пропаганда, начіональні цінності, політична жіноча преса.

Вступ. У Галичині назріла потреба у створенні політичної організації. Такою організацією стала Дружина княгині Ольги, яка утворилася внаслідок постійних переслідувань польською владою членів Союзу українок і припинення його діяльності. Патріотично налаштовані жінки не тільки відчували постійну загрозу з боку польської влади, а й гостру потребу у створенні політичної, а не громадської організації. Тому 1938 року після припинення діяльності Союзу українок утворилася політична жіноча організація Дружина княгині Ольги (М.П. - далі ДКО). Новостворена організація мала не меті поширювати свої погляди та ідеї, пропагувати українську національну ідею серед мас, боротися за визволення свого народу. Керівництво організації прийняло рішення про створення політичного органу для ДКО, який би поширював інформацію про ДКО та їдеї організації. Після закриття «Жінки» організація стала видавати двотижневик «Громадянка». Головним редактором цього часопису була М. Рудницька.

Постановка проблеми. У архівних джерелах зустрічаємо інформацію про «Громадянку» як орган політичної жіночої партії «Дружина княгині Ольги» [5, с. 62]. Часопис постійно конфліктував із владою [6, с. 66]. Неодноразово матеріали двотижневика конфіскувалися , подекуди абзаци, статті i навіть цілі сторінки «небезпечних для влади», матеріалів. Зокрема, у першому числі був конфіскований матеріал: стаття А. Курдидик «Жінки з Чижикова» [2], в якій були подані сфальсифіковані результати виборів до сейму, і в якій йшлося про те, що українців принижують та 
не вважають за людей. I такі конфіскації траплялися часто. Деякі читачки розгублено поглядали на перші сторінки отриманих видань, які були пусті. Тема «Громадянка» і «білі плями» деяких іiі матеріалів» ще не розкрита досі, а це дуже важлива тема. Проте видання залишило помітний слід в історії українського жіночого руху [6, с. 64]. За періодичністю видання було двотижневиком, який виходив у невеликому форматі. На шпальтах часопису маємо редакційні відділи, програмні статті та матеріали про діяльність ДКО.

Мета наукової статті - здійснити огляд кількох номерів жіночого журналу «Громадянка», проаналізувати матеріали національного характеру, в яких пропагується українська національна ідея серед українського жіноцтва.

Методика дослідження. У статті використано низку наукових методів: функціональний (у аналізі ролі видання в загальних суспільно-політичних процесах Галичини); загальний аналіз розвитку жіночої періодики; синтез, хронологічний та типологічний наукові прийоми.

Аналіз останніх досліджень і публікацій. Тему жіночої періодики в Галичині першої половини $\mathrm{XX}$ століття досліджували українські та іноземні науковці. Серед відомих досліджень, присвячених цій тематиці такі: стаття М. Богачевської-Хом'як М. «Союз українок у міжвоєнний період», праці В. Передирій «Часописи «Союзу Українок» і національно-визвольний рух у Галичині (1922-1939)», «Українські періодичні видання для жінок в Галичині (1853-1939рр.)», «Галицька періодика для жінок: становлення, розвиток, проблематика (1853 - 1939 рр.)» та ін.

Вже у редакційні замітці першого числа повідомлялося, що громадськості відомі причини появи нового видання, тому редакція не декламувала програму часопису [2]. Часопис мав чітке політичне спрямування і підтримував організацію «Дружина княгині Ольги», про яку повідомив на своїх сторінках. На створення політичної жіночої організації схвально відгукнулася тодішня західноукраїнська преса: «Діло», «Новий час», «Українські вісті», «Громадський голос».

У першому числі, у редакційній статті, Мілена Рудницька заспокоювала жінок, які боялися політичної партії, а також виражала свою надію на те, що жіночий рух не зникне, що потрібно боротися за свою незалежність з усіх сил: «Мертвих оплакують - живих кличуть!» («Mortuos plango, vivos voco!»): «I справді подивляти нам треба живучости українського жіночого руху, що після сильного потрясіння швидко відроджується в іншій організаційній формі. Привітання нам як нове формування українського жіноцтва. Хіба нові для нас ідеї Дружини Княгині Ольги, висловлені в ііі тезах. Вірність найвищому національному ідеалові і віра в українську жінку як необхідність рівновартісно будувати долю - невже ж ця думка нам незнана з революцій. А Жіночий конгрес? I нехай нас не лякає факт, що Дружина Княгині Ольги - це політична організація, бо живемо в часах, коли для недержавної нації політикою стала і віра батьків, і рідна мова, і хліб насущний, та перед цією політикою ніхто з нас не втече. Нас не лякають труднощі, які будуть - напевне будуть! Бо ми не 3 тих, що лякаються перешкод. Замкнулася одна карта українського жіночого руху, відкрилася нова» [2, c. 1]. Рудницька відверто закликала до політичної боротьби, тобто до гострого протистояння 3 польською владою. Вона висловлює своє бачення українського жіночого руху услужінні найвищому ідеалові. У цій статті йдеться про найвищий ідеал, який авторка бачить у служінні своїй нації, своєму народові. Тобто на перше місце ставиться українська національна ідея, яка стає провідною ідеєю жіночого руху та друкованого органу «Громадянка».

Уже у першому числі були сформульовані тези організації: служити найвищому ідеалові, боротися проти чужинців за свободу своєї нації, любити свою неньку Україну та берегти національні традиції, звичаї, передавати своїм дітям, виховувати дітей у патріотичному дусі для служіння своєї нації, - йдеться у статті «Ідеологічні тези дружини Княгині Ольги» [2]. Молоду організацію захоплено вітали відомі громадські діячки, письменниці. У першому числі опублікована статтявітання новоствореній організації під назвою «Українське жіноцтво вітає Д.К.О.» [2], в якій редакція писала про ідеологічні концепти українського жіночого руху, зокрема служити українській національній ідеї та боротися за незалежну українську державу. Свої захоплення новоствореній організації висловила Софія Русова, що в цей час перебувала у Празі.

Далі у цьому числі надрукована велика стаття про княгиню Ольгу, іменем якої названо організацію «Княгиня св. Ольга - велика володарка» [2] Стефанії Лящинської, в якій йшлося про те, що мужність княгині Ольги повинна передатися українським жінкам; стаття про чергові роковини Л. Українки «В 25-ті роковини смерті Лесі Українки» [2] нагадувала українкам про велич духу, який несла усе своє життя українська поетеса, а також стаття досить великого обсягу про жіночий рух в інших країнах «Жіночий рух на чужині» [2], в якій здійснено глибоку ретроспективу жіночих рухів у світі. Частину матеріалів конфісковано уже у першому числі, насамперед, матеріали про заклики 
до боротьби, політичні статті, нариси про відомих жінок-політиків. І це лише доводило, що ДКО стала серйозною загрозою для польської влади.

Наступне число видання теж конфісковано, зокрема статтю «Нова організація - нові завдання» [3], (конфісковано кілька абзаців), оскільки в цьому матеріалі йшлося про ідейну боротьбу активного українського жіноцтва та статтю «З організаційного життя Д.К.О.» [3], у яких містилися політичні гасла про невизнану українську націю. У четвертій частині журналу конфісковано усю програмну статтю разом із заголовком. Окружний суд у Львові від 23 листопада визнав конфіскацію тільки трьох невеликих абзаців. Стаття втратила свою актуальність для читачів.

Серед публікацій часопису часто можна знайти матеріали про історичні жіночі постаті, зокрема: Ю. Косача «Жанна Д’Арк. До легенди й правди» [4], в якому образ героїні французького народу збагачений жіночими рисами ії характеру. Характери жінок змальовані у замітці Ганни Чикаленко про дослідницю Аляски, Ізабелу Гетченсон та ін. На шпальтах цього видання починає з'являтися такий жанр як інтерв'ю, який раніше використовувався у галицькій періодиці рідко. Зокрема, привертає увагу читачів велике інтерв'ю з популярною на той час співачкою М. Сокіл про її турне по Америці. Постатті легендарної української співачки присвячена стаття «Як Америка приймала М. Сокіл» [4]. Розділ бібліографії не був постійним. Часопис вів рубрику «Книги», де були опубліковані кілька рецензій на прозові твори, відомих письменників цього часу. Літературна сторінка часопису публікувала новели, сучасні переклади іноземної поезії, літературознавчі статті.

Традиційним відділом, який повідомляв про діяльність новоствореної політичної організації був відділ «З організаційного життя Д.К.О.», а «Звідомлення з місць» - повідомлення редакції про місцеві осередки ДКО. Пізніше, з'являється відділ «При громадській роботі», який повідомляв громадськість про акції, проведені ДКО [3]. Про відгуки преси з приводу створення політичної жіночої організації ДКО редакція запровадил відділ «Голоси преси про ДКО». На шпальтах часопису редакція публікувала спогади емігрантів про історичне минуле («Та не буде лучче» [4]).

Результати дослідження. Отже, перегляд кількох чисел і головних публікацій часопису «Громадянка» свідчить про те, що видання пропагувало українську національну ідею як найвищий ідеал для українського суспільства. Публікації авторів пронизані гострою критикою політики польської влади. Жанри часопису представлені статтями, нарисами, замітками, оглядами.

Висновки та перспективи подальших досліджень. Сьогодні пресознавці ввагаються: чи вважати «Громадянку» партійною газетою чи зарахувати іiі до журналів, адже вона повторювала структуру попередніх часописів Союзу українок, але інколи нагадувала за зовнішнім виглядом газету. Періодичність як двотижневик дозволяе «Громадянку» зарахувати до політичних часописів Галичини, на шпальтах якого національний ідеал проголошувався найвищою метою політичної партії ДКО та лунали заклики до боротьби жіноцтва за права своєї нації. Попри постійні переслідування і конфлікти 3 польською владою «Громадянка» стала першим виданням, на шпальтах якого були сформульовані ідеологічні гасла жіночого руху, що перейшов на інший етап свого розвитку, вищий політичний. А друкований політичний орган поширював його ідеї, закликаючи бути не байдужими до свого народу, не боятися переслідувань. «Громадянку» можна назвати політичним типом видання, бо майже усі матеріали, що були надруковані у часописі мали політичний характер. Головною ідеєю, яка пронизувала усі матеріали видання стала українська національна ідея. Пропаганда національної ідеї редакцією була агресивною та непохитною у боротьбі проти польської шовіністичної влади, тому часопис потрібно досліджувати як документальне історичне джерело.

\section{Бібліографічний список:}

1. Богачевська-Хом’як М. Союз українок у міжвоєнний період. Наше життя. 1991. Ч. 2. С. 4-7. (in Ukraine).

2. Громадянка. Ч. 1.1938.

3. Громадянка. Ч. 2. 1938.

4. Громадянка. Ч. 6. 1938.

5. Передирій В. А. Галицька періодика для жінок: становлення, розвиток, проблематика (1853 - 1939 рр.). Збірник праць науково-дослідного центру періодики. 1995. Вип. 2. С. 44-63. (in Ukraine).

6. Передирій В. А. Часописи «Союзу Українок» і національно-визвольний рух у Галичині (1922-1939). Українська періодика: Історія і сучасність. Львів, 1993. С. 64-68. (in Ukraine).

\section{References:}

1. Bohachevska-Khomiak, M. (1991). Soiuz ukrainok u mizhvoiennyi period. [Union of Ukrainian Women in the Interwar Period]. Nashe zhyttia. Ch. 2. S.4-7. (in Ukraine).

2. Hromadianka. (1938). Ch.1. [Hromadianka]. Lviv. (in Ukraine). 
3. Hromadianka. (1938). Ch.2. [Hromadianka]. Lviv. (in Ukraine).

4. Hromadianka. (1938). Ch.6. [Hromadianka]. Lviv. (in Ukraine).

5. Peredyrii, V. (1995). Halytska periodyka dlia zhinok: stanovlennia, rozvytok, problematyka (1853-1939 rr.). [Galician periodicals for women: formation, development, issues (1853-1939)]. Lviv. Zbirnyk Prats naukovodoslidnoho tsentru periodyky. Vyp. 2. S.44-63. (in Ukraine).

6. Peredyrii, V. (1993). Chasopysy «Soiuzu Ukrainok» i natsionalno-vyzvolnyi rukh u Halychyni (1922-1939). [Magazines of the Union of Ukrainian Women and the National Liberation Movement in Galicia (1922-1939). Ukrainska periodyka: Istoriia i suchasnist: tezy dop. i povid. Vseukr. nauk. - teoret. konf. (9-10 hrudnia 1993). Lviv, S. 64-68. (in Ukraine).

Pavlyuh M. V. Magazine of the Union of Ukrainian Women «Hromadianka» as a Political Body of Prince Olga's Squad

The main topics, genres, articles of the magazine of the Union of Ukrainian Women «Hromadianka» are analyzed. Materials in which women promoted the national idea and formed the national consciousness were studied. The main thematic content of the patriotic publication «Hromadianka» is singled out. The organization of the editorial work has been studied: headings and departments. The main publications in which authors of the articles carried out political propaganda against the Polish occupation authorities are presented. It was found out that the publication of the Union of Ukrainian Women "Hromadianka» formed women's patriotism and political consciousness. The main directions of activity of the women's patriotic organization Squad of Princess Olga, which operated in Galicia in the first half of the twentieth century, are indicated.

The Ukrainian national idea became a pervasive idea of the magazine. The organ of the patriotic Ukrainian women's organization Princess Olga's Squad played an important role in the political life of Galicia in the first half of the twentieth century, as it united patriotic women in the struggle for political freedoms. The activity of a woman-mother, a woman-guardian of the family hearth, a woman-patriot was supported by the publication as the main ideological component of many articles. Political propaganda on the pages of the publication "Hromadianka» shaped public opinion, especially rural women, who did not always have the opportunity to read and study.

The article analyzes several important publications that demonstrate the main thematic areas. The publication «Hromadianka» promoted a healthy lifestyle among rural women, as well as formed national values among the population: love for the native language, traditions, customs, culture, homeland. The activities of Princess Olga's Squad and her printed and political body, the Citizen, became widespread in the Galician region, so the Polish occupation regime repeatedly confiscated numbers and issues. The importance, influence and role of the publication "Hromadianka» among the Galician population are significant, as political propaganda against the enemy and the Ukrainian national idea contributed to the liberation struggle of the Ukrainian people in the first half of the twentieth century.

Keywords: women's press, "Princess Olgals Squad", Ukrainian national idea, national consciousness, political propaganda, national values, women's political press. 